\title{
EVALUASI KINERJA KEUANGAN RESTATEMENT DI PT GARUDA INDONESIA (PERSERO) TBK Tahun 2016-2018
}

\author{
YUNANDHA (18179099) \\ Institut bisnis dan keuangan nitro makassar \\ Email:yunandhaabdullah14@gmail.com
}

\begin{abstract}
Abstrak
Penelitian ini adalah untuk mengevaluasi/menganalisis kinerja keuangan restatement di PT Garuda Indonesia (Persero) Tbk.

Metode analisis yang digunakan adalah analisis deskriptif kuantitatif dengan bantuan rasio keuangan dengan menggunakan aspek profitabilitas, aspek likuiditas, aspek manajemen aset dan aspek solvabilitas. Berdasakan SK BUMN No. KEP100/MBU/2002.

Hasil penelitian ini menunjukan bahwa kinerja keuangan PT Garuda Indonesia (Persero) Tbk dari tahun 2016 sampai 2018 masuk predikat "Kurang sehat" berdasarkan SK BUMN No. KEP-100/MBU/2002 ini disebabkan karena kinerja aset untuk memperoleh pendapatan belum optimal, dimana kinerja aset yang tidak efisien akan menimbulkan kerugian.
\end{abstract}

Kata Kunci : Kinerja keuangan, Restatement likuiditas, manajemen aset, profitabilitas, solvabilitas. 


\section{Pendahuluan}

Pada umumnya tujuan setiap perusahaan dalam menjalankan kegiatan usahanya adalah untuk memperoleh laba semaksimal mungkin. Untuk mencapai tujuan tersebut perusahaan harus memiliki produk dan ciri khas yang dapat dipasarkan. Laba tersebut dapat dilihat dari analisis laporan keuangan. Dengan menganalisis laporan keuangan kita dapat menilai bagaimana kinerja keuangan perusahaan tersebut, apakah berada dalam jalur yang tepat. Apabila hasil kinerja keuangan sudah tepat, maka perusahaan akan dapat bersaing dengan perusahaan - perusahaan lain serta mampu mempertahankan kesejahteraan hidup perusahaan.

Persaingan usaha di era globalisasi saat ini sudah semakin kompetitif, tidak terkecuali dengan Perusahaan Badan Usaha Milik Negara (BUMN). Menurut Undang - Undang No 19 Tahun 2003 tentang Badan Usaha Milik Negara (BUMN) adalah badan usaha yang seluruh atau sebagian besar modalnya dimiliki oleh negara melalui penyertaan secara langsung yang berasal dari kekayaan negara yang dipisahan. Adapun salah satu tujuan pendirian BUMN adalah memberikan sumbangan bagi perkembangan perekonomian nasional pada umumnya dan penerimaan negara pada khususnya. Perwujudan dari tujuan tersebut adalah sumbangan besarnya dividen yang diberikan BUMN kepada negara.

Jumlah Perusahaan Badan Usaha Milik Negara (BUMN) dilihat dari statistik perkembangnya pada tahun 2017 sebanyak 115 (www.bumn.go.id). Jumlah ini terbagi dalam beb erapa bidang salah satunya yaitu sarana perhubungan. Salah satu perusahaan BUMN pada bidang perhubungan yaitu PT. Garuda Indonesia (Persero) TBK. PT. Garuda Indonesia (Persero) TBK merupakan perusahaan penerbangan yang komersial di Indonesia. Sebagai salah satu perusahaan penerbangan milik BUMN tentunya perlu menjaga kinerja keuangan agar tetap berada pada kondisi yang sehat. Pada perusahaan milik negara pemerintah telah mengeluarkan kebijakan untuk menilai kesehatan Badan Usaha Milik Negara (BUMN) melalui Surat Keputusan Menteri BUMN No. Kep-100/MBU/2002 yang berisi ketentuan atau tata cara menilai tingkat kesehatan Badan Usaha Milik 
Negara. Salah satu aspek penilaian tingkat kesehatan Badan Usaha Milik Negara (BUMN) yaitu berdasarkan aspek keuangan.

Kinerja keuangan merupakan gambaran dari pencapaian keberhasilan perusahaan dapat diartikan sebagai hasil yang telah dicapai atas berbagai aktivitas yang telah dilakukan (Fahmi, 2012:2). Dengan mengevaluasi kinerja keuangan dapat memberikan gambaran terhadap apa yang telah dicapai oleh perusahaan tersebut. Tidak hanya itu, Kinerja keuangan perusahaan merupakan salah satu faktor yang dilihat oleh para calon investor untuk memutuskan apakah saham perusahaan tersebut layak untuk dibeli atau tidak. Perusahaan juga harus senantiasa menjaga dan meningkatkan kinerja keuangan perusahaannya agar tetap diminati oleh para investor ataupun calon investor (Kirene, dkk. 2017).

Dengan dilakukannya restatement maka memberikan sinyal bahwa laporan keuangan perusahaan yang telah diterbitkan tidak dapat dipercaya. PT. Garuda Indonesia sebagai salah satu perusahaan yang belum lama ini melakukan restatement. Dengan diterbitkannya restatement di Garuda Indonesia, menimbulkan beberapa pertanyaan dan spekulasi tentang laporan keuangan yang disampaikannya.

Menurut Asian Development Bank (ADB)(2018),(Dikutip dalam Daga,2021) Lembaga Keuangan Mikro (microfinance) adalah lembaga yang menyediakan jasa penyimpanan (deposits), kredit (loans), pembayaran berbagai transaksi jasa (payment services) serta money transfers yang ditujukan bagi masyarakat miskin dan pengusaha kecil (insurance to poor and low-income households and their microenterprises). Sedangkan bentuk LKM dapat berupa: lembaga formal misalnya bank desa dan koperasi, (2) lembaga semiformal misalnya organisasi non pemerintah, dan (3) sumber-sumber informal misalnya pelepasan uang.

\section{Tinjauan Pustaka}

\section{Badan Usaha Milik Negara (BUMN)}

\section{a. Pengertian Badan Usaha Milik Negara}


BUMN adalah Badan Usaha Milik Negara yang berbentuk Perusahaan Perseroan (PERSERO) sebagaimana dimaksud dalam Peraturan Pemerintah Nomor 12 Tahun 1998. Badan Usaha Milik Negara (BUMN) merupakan salah satu pelaku kegiatan ekonomi yang penting di dalam perekonomian nasional, yang bersama-sama dengan pelaku ekonomi lain yaitu swasta (besar-kecil, domestik-asing) dan koperasi (www. berkas.dpr.go.id).

BUMN adalah badan usaha yang seluruh atau sebagian besar modalnya dimiliki oleh negara melalui penyertaan secara langsung yang berasal dari kekayaan negara yang dipisahkan. Dengan kata lain BUMN adalah perusahaan yang dikelolah oleh pemerintah dengan tujuan mendorong perkembangan perekonomian nasional.

\section{b. Bentuk - Bentuk Badan Usaha Milik Negara (BUMN)}

Berdasarkan Undang - Undang Republik Indonesia Nomor 19 Tahun 2003 Tentang Badan Usaha Milik Negara, Bentuk - Bentuk Badan Usaha Milik Negara (BUMN) antara lain :

\section{1) Perusahaan Perseorangan}

Perusahaan Perseorangan yang selanjutnya disebut Persero, adalah BUMN yang berbentuk perseorangan terbatas yang modalnya terbagi dalam saham yang seluruh atau paling sedikit $51 \%$ (lima puluh satu persen) sahamnya dimiliki oleh Negara Republik Indonesia yang tujuan utamanya mengejar keuntungan. Adapun maksud dan Tujuan Badan Usaha Perseroan (Persero) adalah menyediakan barang dan jasa yang bermutu tinggi dan berdaya sang kuat serta mengejar keuntungan guna meningkatkan nilai badan usaha. Salah satu contoh BUMN Persero yaitu PT. Garuda Indonesia, PT Pertamina, PT Kimia Farma Tbk, PT Kereta Api

\section{2) Perusahaan Umum}

Perusahaan Umum yang selanjutnya disebut Perum, adalah BUMN yang seluruh modalnya dimiliki negara dan tidak terbagi atas saham, yang bertujuan untuk kemanfaatan umum berupa penyediaan barang dan/atau jasa yang bermutu tinggi dan sekaligus mengejar keuntungan berdasarkan 
prinsip pengelolaan perusahaan. Adapun contoh BUMN Perum yaitu Perum Damri, Perum Bulog, Perum Pegadaian, Perum Percetakan Uang Republik Indonesia (Peruri), dan Perum Balai Pustaka.

\section{Kinerja Keuangan}

\section{a. Pengertian Kinerja Keuangan}

Kinerja keuangan adalah suatu analisis yang dilakukan untuk melihat sejauh mana suatu perusahaan telah melaksanakan dengan menggunakan aturan - aturan pelaksanaan keuangan secara baik dan benar (Munawir, 2014:2). Lain halnya dengan Fahmi (2012:2) yang mengemukakan bahwa kinerja keuangan merupakan gambaran dari pencapaian keberhasilan perusahaan dapat diartikan sebagai hasil yang telah dicapai atas berbagai aktivitas yang telah dilakukan. Kemudian menurut Jumingan (2011:239) kinerja keuangan yaitu merupakan gambaran kondisi keuangan pada suatu periode tertentu baik menyangkut aspek penghimpunan dana maupun penyaluran dana yang biasanya diukur dengan indikator kecukupan modal, likuiditas dan profitabilitas. Dengan demikian kinerja keuangan yaitu gambaran dari kebarhasilan terhadap apa yang telah dilaksanakan oleh perusahaan dengan tujuan yang telah ditetapkan sebelumnya.

\section{b. Tujuan dan Manfaat Kinerja Keuangan}

Tujuan pengukuran kinerja keuangan perusahaan yaitu (Munawir, 2012 : 31) :

1) Mengetahui tingkat likuiditas

Likuiditas adalah kemampuan perusahaan untuk memenuhi kewajiban keuangan yang harus segera diselesaikan pada saat ditagih.

2) Mengetahui Tingkat Solvabilitas

Solvabilitas adalah kemampuan perusahaan untuk memenuhi kewajiban keuangannya jika perusahaan tersebut dilikuidasi, baik keuangan jangka pendek maupun jangka panjang.

3) Mengetahui Tingkat Rentabilitas 
Rentabilitas atau profitabilitas menunjukan kemampuan perusahaan untuk menghasilkan laba selama periode tertentu.

4) Mengetahui Tingkat Stabilitas

Stabilitas adalah kemampuan perusahaan untuk melakukan usaha dengan stabil yang diukur dengan mempertimbangkan kemampuan perusahaan untuk membayar hutangnya serta membayar beban bunga atas hutang tepat pada waktunya.

\section{Penilaian Tingkat Kesehatan BUMN}

Penilaian tingkat kesehatan Perusahaan BUMN berbeda dengan Perusahaan Swasta. Perusahaan BUMN memiliki pedoman yang mengatur penilaian tingkat kesehatan yaitu tertuang dalam Keputusan Menteri Badan Usaha Milik Negara No: KEP-100/MBU/2002.Penilaian tingkat kesehatan BUMN dibedakan antara BUMN yang bergerak dalam bidang infrastruktur dan BUMN yang bergerak dalam bidang non infrastruktur.

BUMN infrastruktur adalah BUMN yang kegiatannya menyediakan barang dan jasa untuk kepentingan masyarakat luas, yang bidang usahanya meliputi:

1) Pembangkitan, transmisi atau pendistribusian tenaga listrik.

2) Pengadaan dan atau pengoperasian sarana pendukung pelayanan angkutan barang atau penumpang baik laut, udara atau kereta api.

3) Jalan dan jembatan tol, dermaga, pelabuhan laut atau sungai atau danau, lapangan terbang dan bandara.

4) Bendungan dan irigasi.

Berdasarkan Keputusan Menteri Badan Usaha Milik Negara Nomor: KEP$100 / M B U / 2002$, tentang penilaian tingakat kesehatan keuangan BUMN yang dinilai berdasarkan total bobot delapan indikator aspek keuangan. 


\section{Metode Penelitian}

\section{A. LOKASI DAN WAKTUPENELITIAN}

Penelitian ini dilaksanakan di Galeri Investasi Institut Bisnis dan Keuangan Nitro Makassar yang berlokasi di Jl. Prof. Abdurahman Basalamah No. 101 Makassar dan waktu yang dibutuhkan untuk penelitian ini diperkirakan kurang lebih satu bulan.

\section{B. JENIS DAN SUMBER DATA}

Adapun jenis dan sumber data yang digunakan dalam penelitian ini adalah :

1. Jenis Data

a. Data kuantitatif, yaitu data yang dikategorikan dalam bentuk angka berupa laporan keuangan PT Garuda Indonesia (Persero) Tbk.

b. Data Kualitatif, yaitu data yang diperoleh dari informasi - informasi sekitar pokok pembahasan, baik lisan maupun tulisan, data ini berupa gambaran umum PT Garuda Indonesia (Persero) Tbk.

2. Sumber Data

Sumber data yang digunakan dalam penelitian ini adalah data sekunder yaitu data yang tidak langsung didapatkan dari objek penelitian tapi diperoleh dalam bentuk data yang telah dikumpulkan, diolah dan dipublikasikan oleh pihak lain yaitu Bursa Efek Indonesia (BEI) melalui Galeri Investasi Intitut Bisnis dan Keuangan Nitro Makassar berupa data laporan keuangan PT Garuda Indonesia (Persero) Tbk.

\section{TEKNIK PENGUMPULAN DATA}

1.Studi Pustaka (library Research) yaitu teknik pengumpulan data dengan cara membaca dan mempelajari teori-teoriatau literature-literatur yang berkaitan dengan penelitian ini.

2.Penelitian Dokumentasi (documentation Resereach) adalah metode pengumpulan data yang dilakukan dengan cara mengumpulkan dokumen-dokumen perusahaan. Dalam penelitian ini penulis menggunakan laporan keuangan PT Garuda Indonesia (Persero) Tbk.

\section{POPULASI DAN SAMPEL}

\section{Populasi}

Populasi dalam penelitian ini adalah semua laporan keuangan PT Garuda Indonesia (Persero) Tbk. 


\section{Sampel}

Sampel yang digunakan dalam penelitian ini adalah laporan keuangan PT. Garuda Indonesia (Persero) Tbk tahun 2016 - 2018

\section{E. DEFINISI OPERASIONAL}

1. Kinerja Keuangan

Kinerja keuangan adalah gambaran pencapaian hasil dari PT Garuda Indonesia (Persero) Tbk dalam hal ini terkait kondisi kesehatan keuangan perusahaan. Kinerja keuangan dalam penelitian ini diukur berdasarkan Keputusan Mentri Badan Usaha Milik Negara Nomor : KEP-100/MBU/2002 Tentang Penilaian Tingkat Kesehatan Badan Usaha Milik Negara dengan menilai empat aspek yaitu aspek profitabilitas, aspek likuiditas, aspekaktivitas / manajemen aset dan aspek solvabilitas.

2. Aspek Profitabilitas

Aspek profitabilitas yaitu aspek yang digunakan untuk menilai kemampuan PT. Garuda Indonesia (Persero) Tbk dalam menghasilkan tingkat laba. Aspek ini diukur dengan rasio :

a. Imbalan Kepada Pemegang Saham/ Return On Equity (ROE)

Return On Equity (ROE) digunakan untuk mengukur pendapatan bagi pemilik PT. Garuda Indonesia (Persero) Tbkterhadap modal yang telah diinvestasikan. Adapun rumus untuk menghitung Return On Equity (ROE)yaitu :

$$
\mathrm{ROE}=\frac{\text { Laba setelah Pajak }}{\text { Modal Sendiri }} X 100 \%
$$

b. Imbalan Investasi/ Return On Investment (ROI)

Return on Investment (ROI) digunakan untuk mengukur hasil (return) terhadap jumlah aktiva yang digunakan dalam PT. Garuda Indonesia (Persero) Tbk serta ukuran bagi efektivitas manajemen dalam mengelola investasinya. Rumus untuk menghitung return on investment (ROI)yaitu :

$$
\text { ROI }=\frac{\text { EBIT }+ \text { Penyusutan }}{\text { Capital Employed }} \times 100 \%
$$

\section{Aspek Likuiditas}


Aspek likuiditas yaitu aspek yang menggambarkan kemampuan PT. Garuda Indonesia (Persero) Tbk untuk memenuhi kewajiban jangka pendek. Aspek ini diukur dengan rasio :

\section{a. Rasio Kas/Cash Ratio}

Cash Ratio merupakan rasio yang digunakan untuk mengukur kemampuan PT. Garuda Indonesia (Persero) Tbk untuk membayar hutang jangka pendeknya dengan uang kas yang tersedia. Penilaian cash ratio dapat dihitung dengan menggunakan rumus :

$$
\text { Cash Ratio }=\frac{\text { Kas }+ \text { Bank }+ \text { Surat Berharga Jangka pendek }}{\text { Current Liabilities }} X 100 \%
$$

\section{b. Rasio Lancar/Current Ratio}

Current ratio digunakan untuk mengukur kemampuan PT. Garuda Indonesia (Persero) Tbk dalam memenuhi kewajiban jangka pendek. Adapun rumus untuk mengukur Current Ratio yaitu :

$$
\text { Current Ratio }=\frac{\text { Current Asset }}{\text { Current Liabillities }} \times 100 \%
$$

4. Aspek Aktivitas/Manajemen Aset

Aspek aktivitas adalah aspek yang menggambarkan seberapa efektif PT. Garuda Indonesia (Persero) Tbk dalam memanfaatkan aset yang dimilikinya. Aspek ini diukur dengan rasio :

a. Collection Periods (CP)

Collection Periods (CP) yaitu menunjukan jumlah hari yang dibutuhkan PT. Garuda Indonesia (Persero) Tbk dalam melakukan penagihan piutang. Rumus untuk menghitung Collection Periods (CP) yaitu :

$$
\mathrm{CP}=\frac{\text { Total Piutang Usaha }}{\text { Total Pendapatan Usaha }} X 365 \%
$$

b. Perputaran Persediaan (PP)

Perputaran Persediaan digunakan untuk mengukur berapa kali PT. Garuda Indonesia (Persero) Tbk menjual persediaan dalam suatu periode bersangkutan. Adapun rumus untuk menghitung perputaran persediaan yaitu :

$$
\mathrm{PP}=\frac{\text { Total Persediaan }}{\text { Total Pendapatan Usaha }} \times 365 \%
$$

c. Perputaran Total Aset/ Total Asset Turn Over (TATO) 
Total Asset Turn Over (TATO) digunakan untuk mengukur kemampuan total aset PT. Garuda Indonesia (Persero) Tbk dalam menghasilkan pendapatan bagi perusahaan. Ada pun rumus untuk menghitung Total Asset Turn Over yaitu :

$$
\text { TATO }=\frac{\text { Total Pendapatan }}{\text { Capital Employed }} X 100 \%
$$

\section{Aspek Solvabilitas}

Aspek solvabilitas yaitu aspek yang menggambarkan kemampuan PT. Garuda Indonesia (Persero) Tbk untuk memenuhi semua kewajibannya, baik kewajiban jangkapendek maupun kewajiban jangka panjang. Aspek ini diukur dengan Rasio Total Modal Sendiri (TMS) terhadap Total Aset (TA). Rasio ini digunakan untuk mengukur jumlah aset dari modal sendiri. Adapun rumus untuk menghitung Rasio Total Modal Sendiri (TMS) terhadap Total Aset (TA) yaitu :

$$
\text { TMS terhadap TA }=\frac{\text { Total Modal Sendiri }}{\text { Total Asset }} X 100 \%
$$

\section{F. ANALISIS DATA}

1. Metode analisis

Metode analisis yang digunakan dalam penelitian ini adalah analisis deskriptif kuantitatif dengan bantuan rasio keuangan.

\section{Alat Analisis}

Alat analisis data yang digunakan dalam penelitian ini adalah rasio keuangan berdasarkan SK BUMN NO. KEP-100/MBU/2002, yaitu :

\section{a. Aspek Profitabilitas}

Aspek profitabilitas yaitu aspek yang digunakan untuk menilai kemampuan perusahaan dalam menghasilkan tingkat laba.

b. Aspek Likuiditas

Aspek likuiditas yaitu aspek yang menggambarkan kemampuan suatu perusahaan untuk memenuhi kewajiban jangka pendek.

c. Aspek Aktivitas/Manajemen Aset

Aspek aktivitas adalah aspek yang menggambarkan seberapa efektif perusahaan dalam memanfaatkan aset yang dimilikinya.

d. Aspek Solvabilitas 
Aspek solvabilitas yaitu aspek yang menggambarkan kemampuan perusahaan untuk memenuhi semua kewajibannya, baik kewajiban jangka pendek maupun kewajiban jangka Panjang.

\section{Kesimpulan}

Kinerja keuangan merupakan gambaran dari pencapaian keberhasilan perusahaan dapat diartikan sebagai hasil yang telah dicapai atas berbagai aktivitas yang telah dilakukan.

Terdapat empat aspek yaitu :
1) aspek profitabilitas,
2) aspek likuiditas,
3) aspek aktivitas / manajemen aset dan
4) aspek solvabilitas.

\section{DAFTAR PUSTAKA}

Fahmi, Irham, 2015. Analisis Laporan Keuangan, Bandung : Penerbit Alfabeta.

Jamal, Atika, 2019. Kinerja Keuangan PT. Telekomunikasi Indonesia (Persero) Tbk. Sekolah Tinggi Ilmu Manajemen Nitro Makassar.

Jumingan, 2011. Analisis Laporan Keuangan. Jakarta : Bumi Aksara.

Kasmir, 2014. Analisis Laporan Keuangan. PT. Rajagrafindo Persada : Jakarta Edisi ketujuh. 
Kirene, Gregorius, dkk, 2017. Analisis Rasio Keuangan Untuk Menilai Kinerja Keuangan Pt. Garuda Indonesia (Persero) Tbk (Periode 2010 - 2014). Universitas Katolik Widya Karya.

Kusumo, Widi Ridho, 2014. Analisis Pengaruh Karakteristik Corporate Governance Terhadap Keterjadian Restatement. Universitas Diponegoro Semarang.

Munawir, 2012. Analisis Informasi Keuangan, Yogyakarta : Liberty.

Pertami, Fauziah Yuli Surya, 2016. Pengaruh Restatement Laporan Keuangan Terhadap Abnormal Return. Universitas Sangga Buana.

Rudjito, Tanty, 2018. Analisis Kinerja Keuangan Pada PT. Pembangunan Perumahan (Persero) Tbk. Sekolah Tinggi Ilmu Manajemen Nitro Makassar.

Yulia, 2018. Analisis Kinerja Keuangan Pt. Wijaya Karya (Persero) Tbk Periode 2012 2016. Amik Bsi Pontianak.

Daga, R., \& Taufiq, H. I. (2018). Persepsi Pengusaha Mikro Terhadap Lembaga Keuangan Mikro di Makassar. 
